\title{
Revised Description, from Clinical Strains, of Flavobacterium breve (Lustig) Bergey et al. 1923 and Proposal of the Neotype Strain
}

\author{
B. HOLMES, J. J. S. SNELL, AND S. P. LAPAGE \\ National Collection of Type Cultures, Central Public Health Laboratory, London NW9 5HT, \\ United Kingdom
}

Flavobacterium breve (Lustig 1890) Bergey et al. 1923 was originally meagerly characterized in comparison with the wide range of characterization tests now available, and subsequent descriptions of this species have been few and incomplete. No type strain was designated for $F$. breve, and no neotype appears to have been proposed. Six strains from a collection of 1,700 gram-negative, nonfermentative clinical strains submitted to the National Collection of Type Cultures for computer-assisted identification during the last 10 years and one strain (ATCC 14234) maintained in a culture collection as $F$. breve conformed to the original and subsequent descriptions of $F$. breve. One of these seven strains, CL88/76 (= NCTC 11099), is herein proposed as the neotype strain of $F$. breve. These seven strains have been examined in a large number of biochemical tests and in their susceptibility to a range of antimicrobial agents in order to provide a revised description of the species by which it may be more easily recognized in clinical material. One of our clinical strains died before its susceptibility could be determined, but the remaining five, together with ATCC 14234, were resistant to carbenicillin and gentamicin, and the five clinical strains examined were also resistant to several other antimicrobial agents generally useful in the treatment of infections caused by gram-negative, nonfermentative bacteria. This suggests that infections due to this species could prove to be difficult to treat.

In 1888 , Mori (25) isolated from canal water three organisms that he found pathogenic for laboratory animals; he referred to one of the three organisms simply as "the short canal bacillus." This organism has been variously named Bacillus brevis by Lustig (19) in 1890 , a name also used by Frankland and Frankland (12) in 1894; as Bacillus canalicolis brevis by Cornil and Babes (8) in 1890; and as Bacillus canalis parvus by Eisenberg (11) in 1891. Chester (6) referred to the organism as Bacterium canalis parvus and drew attention to the similarity between this species and Bacterium septicus agrigenus (Flügge) Chester 1897. $\mathrm{Mez}$ (24) used the name Bacterium canale for the Bacillus canalis parvus of Eisenberg (11).

Although the name Bacillus brevis was originally proposed by Lustig (19), it has been mistakenly attributed to Frankland and Frankland (12) by Chester (7), who used the name Bacterium breve, by Bergey et al. (2) when they transferred Bacillus brevis to the genus Flavobacterium as Flavobacterium brevis (sic), and by Krasil'nikov (16) on transferring $F$. breve to the genus Pseudobacterium as Pseudobacterium brevis (sic).

Despite transfer of this organism to Pseudo- bacterium by Krasil'nikov (16) and to Empedobacter as Empedobacter breve (sic) by Prévot (26), its transfer to the genus Flavobacterium by Bergey et al. (2) has gained some acceptance. Stutzer and Kwaschnina (27) used the name $F$. brevis (sic) when giving their description of the species, and Weeks (29) included the $B$. brevis of Lustig (19) in the genus Flavobacterium, correcting the ending of the specific epithet so that the name of the species is now $F$. breve (Lustig) Bergey et al. 1923.

A list of culture collections holding strains of either Flavobacterium breve or Bacillus brevis was obtained from the World Data Center for Microorganisms (Department of Microbiology, University of Queensland, St. Lucia, Queensland 4067, Australia). However, the strains maintained in the culture collections that replied to our request for information were members of $B$. brevis Migula 1900, a gram-positive bacterium, and not $B$. brevis Lustig 1890 . The only strain of $F$. breve we were able to obtain for comparative purposes, ATCC 14234, is not one of Lustig's original strains but is apparently a strain of the Ajinomoto Co. (1).

The present account reports clinical details relating to the isolation of six field strains sub- 
mitted to us for identification and the results of biochemical tests, antimicrobial susceptibility tests, and determinations of deoxyribonucleic acid (DNA) base compositions obtained from an examination of these six strains and ATCC 14234.

\section{MATERIALS AND METHODS}

Bacterial strains. The identities and sources of the seven strains studied are given in Table 1.

Strain 1 was isolated from a male patient, but the site of isolation was not stated and further details could not be obtained.

Strain 2 was isolated from the swab of an irritated eye of a nurse engaged in the special nursing of a neonate in an intensive care unit. The condition was treated with chloramphenicol eye ointment and cleared rapidly.

Strain 3 was recovered from the bronchial secretion of a 70-year-old female patient with chronic bronchitis. The bronchial secretion contained a medium number of leukocytes, epithelial cells, gram-negative rods, and a large number of gram-positive cocci in pairs. Upon culture of the secretion, a large number of enterococci grew, as well as strain 3 .

Strain 4, isolated in the Zurich area independently from strain 3 , was found in a blood culture of a patient with suspected endocarditis. The strain, isolated only once, was referred to J. Wüst for identification. The patient was treated according to the antimicrobial susceptibility of the strain and has remained well. It was not possible to determine whether this strain was causative of a pathological process or was merely a contaminant.

Strain 5 came from a 38-year-old female patient with a history of chronic pyelonephritis, cholelithiasis, and nephrogenic hypertension. Bacteriological examination of the urine revealed a mixed culture $\left(>10^{5}\right.$ bacteria per ml) containing Acinetobacter calcoaceticus, Escherichia coli, and strain 5. The infection responded to chloramphenicol therapy, and the patient was allowed to go home.

Strain 6 was isolated from a 32 -year-old female patient admitted to the hospital with proteinuria, hypertension during pregnancy, and edema of the lower extremities. The urine contained a mixture $\left(10^{4}\right.$ to $10^{5}$ bacteria per ml) of Klebsiella oxytoca and strain 6 . After a normal delivery, the hypertension and edema cleared without complications. Further biochemical or bacteriological examination of the urine was not carried out.

Bacteriological investigations. The strains were subcultured on nutrient agar (Oxoid CM 67, $25 \mathrm{~g}$; New Zealand agar, $12 \mathrm{~g}$; per liter of distilled water) under aerobic conditions for 18 to $24 \mathrm{~h}$ at their optimum growth temperature, $30^{\circ} \mathrm{C}$. Colonial morphology was described from aerobic growth on nutrient agar and $5 \%$ (vol/vol) horse blood agar. Pigmentation was recorded from growth on nutrient and tyrosine agars (9), and fluorescence was tested for on medium B of King et al. (15). The Gram reaction was determined by the Lillie modification as described by Cowan (9). Motility was tested by the.hanging-drop method on overnight cultures grown at room temperature $\left(18\right.$ to $\left.22^{\circ} \mathrm{C}\right)$ and at $37^{\circ} \mathrm{C}$ in nutrient broth (Oxoid $\mathrm{CM} 67$ ).

The biochemical characteristics investigated are listed in Table 2. The methods used for these tests have been described by Holmes et al. (13) with the following changes or additions. Indole production was tested with Kovács reagent, and with Ehrlich reagent by method 3 of Cowan (9). Phosphatase production was determined by method 1 of Cowan (9). Acid production was also tested for in oxidation-fermentation medium containing carbohydrates at a concentration of $1 \%$ (wt/vol). Growth inhibition by $0.1 \%$ (wt/vol) 2,3,5-triphenyl-tetrazolium chloride (Koch-Light Laboratories Ltd., Colnbrook) incorporated into nutrient agar was also tested.

Susceptibility to antimicrobial agents was tested by an agar-dilution method. Twofold dilutions of antimicrobial agents were added to Diagnostic Sensitivity Test agar (Oxoid Ltd., London) to give a range of concentrations of 128 to $0.006 \mu \mathrm{g} / \mathrm{ml}$. Lysed horse blood $(2 \%, \mathrm{vol} / \mathrm{vol})$ was added to medium containing sulfonamide or cotrimoxazole. The medium was dispensed into petri dishes, which were inoculated, using a replicating device, with $0.003-\mathrm{ml}$ volumes of overnight broth cultures of strains diluted to contain about $10^{5}$ cells per ml. Each plate was also inoculated with three control strains of known susceptibility: Escherichia coli NCTC 10418, Pseudomonas aeruginosa

TABLE 1. Sources of seven $F$. breve strains studied

\begin{tabular}{|c|c|c|c|}
\hline Strains & Original strain designation & Source & Site of isolation \\
\hline \multicolumn{4}{|l|}{ Field strains } \\
\hline 1 & CL200/75 & P. Unsworth, London & Unknown \\
\hline 2 & CL626/75 (= NCTC 11162) & M. Byrne, Dublin & Eye swab \\
\hline 3 & CL 88/76 (= NCTC 11099) & J. Wüst, Zurich & $\begin{array}{l}\text { Bronchial se- } \\
\text { cretion }\end{array}$ \\
\hline 4 & CL239/76 & J. Wüst, Zurich & Blood culture \\
\hline 5 & CL666/76 & $\begin{array}{l}\text { P. Kohút and M. Rusinko, } \\
\text { Bratislava, Czechoslo- } \\
\text { vakia }\end{array}$ & Urine \\
\hline 6 & CL669/76 (= NCTC 11163) & $\begin{array}{l}\text { P. Kohút and M. Rusinko, } \\
\text { Bratislava, Czechoslo- } \\
\text { vakia }\end{array}$ & Urine \\
\hline $\begin{array}{l}\text { Culture collection strain } \\
\text { (ATCC 14234) }\end{array}$ & & $\begin{array}{l}\text { American Type Culture Col- } \\
\text { lection }\end{array}$ & Unknown \\
\hline
\end{tabular}


TABLE 2. Biochemical characteristics of seven strains of Flavobacterium breve

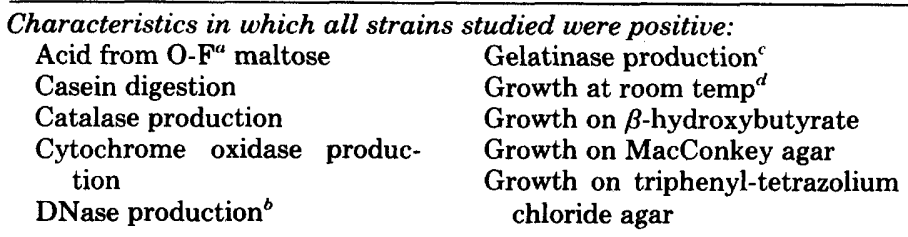

Characteristics in which all strains studied were negative:

Acid from the following ammonium salt sugars:

\section{Adonitol}

Arabinose

Cellobiose

Dulcitol

Ethanol

Fructose

Galactose

Glycerol

Inositol

Lactose ${ }^{e}$

Mannitol $^{e}$

Raffinose

Rhamnose

Salicin

Sorbitol

Sucrose $e^{e}$

Trehalose

$\mathrm{Xylose}^{e}$

Acid from PWS $^{f}$ glucose

Acid from $10 \%$ (wt/vol) glucose
Acid from 10\% (wt/vol) lactose

Alkali production on Christensen citrate

Arginine desimidase

Arginine dihydrolase

Esculin hydrolysis

Fluorescence on King medium B

Gas from PWS glucose

Gluconate oxidation

Growth at $5^{\circ} \mathrm{C}$

Growth at $42^{\circ} \mathrm{C}$

Growth on cetrimide agar

Growth on Salmonella-Shigella (SS) agar

Growth on Simmons citrate

Growth on media containing $6 \%$ (wt/vol) $\mathrm{NaCl}$

Hydrogen sulfide production ${ }^{p}$

Indole production (Kovács reagent)

$\mathrm{KCN}$ tolerance

Lysine decarboxylase
Indole production (Ehrlich reagent)

Phosphatase production

Production of yellow pigment

Tween 20 hydrolysis

Malonate utilization

Motility ${ }^{h}$

Nitrate reduction

Nitrite reduction

Opalescence on lecithovitellin agar

Ornithine decarboxylase

Phenylalanine deamination

Pigment production on tyrosine agar

Poly- $\beta$-hydroxybutyrate inclusion granules

Reduction of $0.4 \%(\mathrm{wt} / \mathrm{vol})$ selenite

Starch hydrolysis

Tyrosine hydrolysis

Urease production

$\beta$-Galactosidase production

3-Ketolactose production

\begin{tabular}{|c|c|c|c|}
\hline $\begin{array}{l}\text { Characteristics in which there were } \\
\text { strain differences: }\end{array}$ & No. of strains positive & $\begin{array}{l}\text { Result of neotype } \\
\text { strain (CL } 88 / 76 \text { ) }\end{array}$ & $\begin{array}{l}\text { Reference no. of strains that gave } \\
\text { the less common result }\end{array}$ \\
\hline Acid from ASS $^{i}$ glucose & $6 / 7$ & + & $4^{j}$ \\
\hline Acid from ASS maltose & $6 / 7$ & + & $4^{k}$ \\
\hline Growth at $37^{\circ} \mathrm{C}$ & $6 / 7$ & + & ATCC 14234 \\
\hline Gelatin stab liquefaction & $5 / 7$ & + & 6 and ATCC 14234 \\
\hline Tween 80 hydrolysis & $3 / 7$ & - & $1,5,6$ \\
\hline $\begin{array}{l}\text { Hugh and Leifson O-F glu- } \\
\text { cose medium }\end{array}$ & $3 \mathrm{oxi} / 4$ neg $^{m}$ & Oxidative & 2,3 , and ATCC 14234 \\
\hline
\end{tabular}

${ }^{a}$ Hugh and Leifson oxidation-fermentation (O-F) medium.

${ }^{b}$ ATCC 14234 was negative on deoxyribonuclease (DNase) agar incorporating toluidine blue; a positive result was obtained with this strain by flooding a DNase agar plate with $\mathrm{N}-\mathrm{HCl}$.

'By plate method.

${ }^{d} 18$ to $22^{\circ} \mathrm{C}$.

${ }^{e}$ Also negative in Hugh and Leifson O-F medium.

${ }^{f}$ PWS, Peptone-water-sugar medium.

* By both lead acetate paper and triple sugar iron (TSI) agar methods.

${ }^{h}$ At both $37^{\circ} \mathrm{C}$ and room temperature in hanging drop.

${ }^{i}$ ASS, Ammonium salt sugar medium.

'Becomes acid after incubation for 17 days.

${ }^{k}$ Becomes acid after incubation for 7 days.

${ }^{i} \mathrm{pH}$ of medium at time of inoculation 6.9 .

${ }^{m}$ Three strains oxidative; four strains negative.

NCTC 10662, and Staphylococcus aureus NCTC 6571. The minimum inhibitory concentration of an antimicrobial agent for each strain was defined as the lowest concentration completely inhibiting growth after overnight incubation at $30^{\circ} \mathrm{C}$.

DNA base compositions. DNA was extracted by the method of Marmur (21) and was purified by treatment with protease and phenol as described by Bren- ner et al. (3). The melting temperature $\left(T_{m}\right)$ determinations were made in saline sodium citrate buffer in a Pye Unicam SP 1800 spectrophotometer equipped with an electrically heated cell holder and a temperature programmer. The temperature of the DNA was raised $0.25^{\circ} \mathrm{C} / \mathrm{min}$, and absorbance was recorded on a Pye Unicam AR 25 series linear-strip chart recorder. The temperature of the DNA solution was measured 
at $0.5^{\circ} \mathrm{C}$ intervals with a thermistor bead inserted in the sample cuvette and a temperature-reading meter. The thermistor bead and meter were calibrated against a thermometer calibrated at the National Physical Laboratories, with both bead and thermometer immersed in an oil bath to a depth of $8 \mathrm{~cm}$.

The equation used to relate $T_{m}$ to guanine-pluscytosine $(\mathrm{G}+\mathrm{C})$ content was that of Mandel et al. (20):

$$
\begin{aligned}
& \mathrm{mol} \% \mathrm{G}+\mathrm{C}_{\text {unknown }}=\mathrm{mol} \% \mathrm{G}+\mathrm{C}_{\text {reference strain }} \\
&+ {\left[\text { slope of equation } \times\left(T_{m} \text { unknown }-\right.\right.} \\
&\left.\left.T_{m} \text { reference strain }\right)\right]
\end{aligned}
$$

A value for the slope of the equation, 2.44, was derived from the data of Marmur and Doty (22) and De Ley (10). The average $T_{m}$ from several determinations of the reference DNA extracted from $E$. coli $\mathrm{K}-12(\mathrm{G}+\mathrm{C}$ $=51 \mathrm{~mol} \%$ ) was 91.05 . Substituting values for the slope of the equation and for $T_{m}$ and $\mathrm{G}+\mathrm{C}$ content of the reference strain in equation 1 gives:

$$
\mathrm{mol} \% \mathrm{G}+\mathrm{C}=51+\left[2.44 \times\left(T_{m}-91.05\right)\right]
$$

\section{RESULTS}

The strains were gram-negative rods that produced yellow colonies on nutrient agar. After incubation for $24 \mathrm{~h}$ on nutrient agar and on blood agar, the colonies of all strains had an entire edge, were low convex (strain 4 was domed), circular, smooth, shining, and pale yellow in color (strain 6 was pale yellow on nutrient agar, opaque gray on blood agar). Colonies were nonhemolytic on blood agar (strain 3 showed alpha-hemolysis) and were slightly larger on the average than on nutrient agar. Colony size varied between the strains, and, whereas some strains produced colonies each of uniform diameter, others produced colonies which varied in diameter. The sizes of the colonies produced by all of the strains ranged from 0.25 to $2.5 \mathrm{~mm}$ on blood agar and from 0.25 to $2.0 \mathrm{~mm}$ on nutrient agar. Colonies of ATCC 14234 were smaller on the average (not exceeding $1.0 \mathrm{~mm}$ ) and were the same size on blood agar as on nutrient agar. After incubation on nutrient agar for 7 days, colonies of all of the strains had an entire edge, were low convex (strain 6 had raised colonies coming to a point in the center), circular, smooth, shiny, and yellow in color (strain 6 was cream and ATCC 14234 was orange). The diameters of the colonies produced by all of the strains ranged from 0.5 to $5.0 \mathrm{~mm}$. After incubation on blood agar for 7 days, the colonies generally had yellow centers with greenish edges and showed beta-hemolysis. The colony diameter did not exceed $7.0 \mathrm{~mm}$.

The biochemical test results for the strains are given in Table 2 . The strains were very homogeneous with respect to their biochemical characteristics, for there were differences be- tween the strains in only 6 of the 73 tests carried out. Although the strains gave negative results for most of the biochemical characters tested, the strains have several distinguishing characteristics by which they may be recognized: all of the strains produced a yellow pigment on nutrient agar; no characteristic odor was produced; they were all nonmotile; and they produced small amounts of acid solely from glucose and maltose of the 20 carbohydrates tested. Acid was sometimes produced in ammonium salt sugar medium (13) only after incubation beyond 5 days and only at $30^{\circ} \mathrm{C}$, the temperature for optimum growth of the strains, and not at $37^{\circ} \mathrm{C}$, although all but ATCC 14234 grew at this temperature. Casein was digested, and extracellular deoxyribonuclease and gelatinase were also produced by all of the strains. All of the strains produced indole, but a sensitive method (utilizing Ehrlich reagent) was necessary to demonstrate the presence of indole.

The results of the susceptibility tests to antimicrobial agents are given in Table 3. ATCC 14234 was more susceptible to each of the antimicrobial agents tested than were the clinical strains. One of the clinical strains unfortunately died before its susceptibility could be determined. The five clinical strains tested were fully resistant to therapeutic levels of streptomycin, gentamicin, kanamycin, ampicillin, carbenicillin, and polymyxin $B$, were resistant or moderately resistant to sulfamethoxazole, cotrimoxazole, cephaloridine, erythromycin, chloramphenicol, and tetracycline, and were moderately susceptible to nalidixic acid.

For the three strains examined, the $T_{m}$ values and DNA base compositions $(\mathrm{G}+\mathrm{C})$ were: strains 2 and $3,83.7^{\circ} \mathrm{C}, 33.1 \mathrm{~mol} \%$; ATCC $14234,83.1^{\circ} \mathrm{C}$, $31.6 \mathrm{~mol} \%$.

\section{DISCUSSION}

Lustig (19) did not designate the type strain of $B$. brevis, and no neotype appears to have been proposed for this species. Our six field strains and ATCC 14234 conform to the original description of the species (18) in being gram negative, nonmotile, and yellow pigmented. The only result that we found at variance with the original description was that, although two of the strains failed to liquefy gelatin, the remaining five were able to do so, and all seven strains produced gelatinase as demonstrated by the sensitive plate method.

In addition to producing gelatinase, the seven strains differed from the descriptions of $F$. breve summarized by Weeks (29) in failing to grow on media containing $6 \%$ (wt/vol) $\mathrm{NaCl}$, in digesting casein, and in producing indole. These discrep- 
TABLE 3. Susceptibility of F. breve to antimicrobial agents

\begin{tabular}{|c|c|c|c|c|c|c|c|c|c|}
\hline \multirow{3}{*}{$\begin{array}{c}\text { Antimicrobial } \\
\text { agent }\end{array}$} & \multicolumn{9}{|c|}{ Susceptibility $^{a}$ of: } \\
\hline & \multicolumn{6}{|c|}{$F$. breve strain } & \multirow{2}{*}{$\begin{array}{c}\text { Pseudo- } \\
\text { monas } \\
\text { aeruginosa } \\
\text { NCTC } \\
10662\end{array}$} & \multirow{2}{*}{$\begin{array}{c}\text { Staphylococ- } \\
\text { cus aureus } \\
\text { NCTC } 6571\end{array}$} & \multirow{2}{*}{$\begin{array}{c}\text { Esche- } \\
\text { richia } \\
\text { coli } \\
\text { NCTC } \\
10418\end{array}$} \\
\hline & 1 & 2 & 3 & 5 & 6 & $\begin{array}{c}\text { ATCC } \\
14234\end{array}$ & & & \\
\hline Sulfamethoxazole & 64 & 32 & 16 & 32 & 128 & 2 & 64 & 2 & 4 \\
\hline Cotrimoxazole ... & 8 & 4 & 4 & 8 & 8 & 1 & 32 & 0.5 & 0.5 \\
\hline Streptomycin & 128 & 128 & 128 & 128 & 64 & 4 & 32 & 4 & 8 \\
\hline Gentamicin & 32 & 64 & 32 & 64 & 32 & 2 & 1 & 0.25 & 1 \\
\hline Kanamycin & $>128$ & $>128$ & $>128$ & $>128$ & $>128$ & 64 & 64 & 2 & 2 \\
\hline Ampicillin & 64 & 64 & 64 & 64 & 128 & 16 & 128 & 0.25 & 4 \\
\hline Carbenicillin & 64 & 128 & 64 & 64 & 128 & 32 & 32 & 1 & 4 \\
\hline Cephaloridine & 8 & 16 & 8 & 8 & 0.5 & 0.25 & $>128$ & 0.03 & 4 \\
\hline Erythromycin & 0.5 & 0.5 & 0.5 & 1 & 1 & 0.06 & 128 & 0.125 & 8 \\
\hline Chloramphenicol & 8 & 8 & 8 & 16 & 8 & 1 & 16 & 2 & 2 \\
\hline Tetracycline .... & 8 & 4 & 4 & 8 & 4 & 0.5 & 8 & 0.125 & 1 \\
\hline Polymyxin B & 32 & 64 & 32 & $>128$ & 64 & 8 & 2 & 128 & 0.25 \\
\hline Nalidixic acid & 16 & 16 & 8 & 16 & 8 & 16 & 32 & 32 & 1 \\
\hline
\end{tabular}

${ }^{a}$ Minimum inhibitory concentration (micrograms per milliliter).

ancies can, however, be explained on the basis that the tests used in this study for gelatinase production, casein digestion, and indole production are known to be more sensitive than older methods. The discrepancy between our values of 31.6 to $33.1 \mathrm{~mol} \% \mathrm{G}+\mathrm{C}$ and the value of 26 mol\% G+C given by Weeks (29) for $F$. breve was resolved by Weeks in a personal communication. Weeks informed us that his published $\mathrm{G}+\mathrm{C}$ value for $F$. breve was obtained from an examination of ATCC 14234, and, upon reexamining this strain, he found the value to be $32.7 \mathrm{~mol} \%$ $\mathrm{G}+\mathrm{C}$, in good agreement with our figure of 31.6 mol\% $\mathrm{G}+\mathrm{C}$ for this same strain.

The early descriptions of $F$. breve were so incomplete that it is not possible to be absolutely certain that our strains belong to this species. However, our findings are in reasonable accord with perhaps the best early description of $F$. breve, that given by Stutzer and Kwaschnina (27) under the name $F$. brevis (sic) in 1929. They described the species as being nonmotile and gram negative and as producing on agar flat convex colonies, not more than $1.0 \mathrm{~mm}$ in diameter, with smooth edges, a shiny flat surface, and a yellow color; this colonial description agrees very closely with ours. Stutzer and Kwaschnina (27) further described the species as not liquefying gelatin (two of our strains failed to liquefy gelatin), failing to produce indole and hydrogen sulfide, and not reducing nitrates; most important of all, they noted weak acid production from glucose (they also found acid production from galactose, but we were unable to confirm this finding). One of the most notable characters of our strains was their ability to produce acid from glucose in ammonium salt sugar medium only when incubated at $30^{\circ} \mathrm{C}$ and sometimes only after prolonged incubation (up to 17 days). For the foregoing reasons, we consider that these strains may reasonably be ascribed to $F$. breve.

None of the strains examined here was from the collection of the author who first described the species (19), and therefore any of the seven strains we examined could be proposed as the neotype strain. We proposed CL88/76 (= NCTC 11099 ) as the neotype strain of $F$. breve because it was one of four strains which were centrotypes of our group of seven strains (17). The remaining five field strains and ATCC 14234 conform closely to the proposed neotype in biochemical characters, susceptibility to antimicrobial agents, and in DNA base composition (Tables 2 and 3 ). We therefore consider our remaining five field strains and ATCC 14234 to be members of $F$. breve. We chose not to propose ATCC 14234 as the neotype strain since, although it is already held in a culture collection, it was the least typical of the seven strains examined and differed from the proposed neotype and the other five clinical strains in failing to grow at $37^{\circ} \mathrm{C}$ and failing to produce extracellular deoxyribonuclease on deoxyribonuclease agar incorporating toluidine blue. It was also more susceptible to all of the antimicrobial agents tested than were any of the five clinical strains examined. ATCC 14234 failed to liquefy gelatin (as did one of our clinical strains) and accords to the original description of $F$. breve in this respect; however, this is a minority result among our strains and therefore further precludes the suitability of ATCC 14234 as a suitable neotype strain for $F$. breve. In all other characters, however, the seven strains agree, and we do not hesitate to include ATCC 14234 together with the other six strains 
in the same species. The source of ATCC 14234 is not listed in the ATCC Catalogue of Strains (1) and, if this strain did not come from a clinical source, its probable lack of contact with antimicrobial agents would reasonably explain its greater susceptibility in comparison with the five clinical strains examined.

Salient features for the recognition of $F$. breve are lack of motility; production of yellow pigment; production of cytochrome oxidase, proteinases, deoxyribonuclease, and phosphatase; weak or delayed acid production from glucose and maltose in ammonium salt agar medium; and resistance to carbenicillin, gentamicin, and polymyxin. The DNA base composition of $F$. breve is in the range of 31 to $33 \mathrm{~mol} \% \mathrm{G}+\mathrm{C}$. Other characters of this species are listed in Tables 2 and 3.

Five organisms occasionally isolated from clinical material may be confused with $F$. breve, namely $F$. meningosepticum, $F$. odoratum (14), Pseudomonas maltophilia, and groups IIb and IIf of Weaver et al. (28). Characters by which these organisms can be differentiated from each other are given in Table 4. Occasional strains of Pseudomonas maltophilia produce a yellow pigment, and, because the majority produce acid from glucose and almost all produce acid from maltose, they could be confused with $F$. breve; however, $P$. maltophilia is motile whereas $F$. breve is not. $F$. meningosepticum and the biochemically similar group IIb produce acid from glucose and maltose, as does $F$. breve, but they differ from $F$. breve in also producing acid from glycerol and trehalose and in hydrolyzing esculin. $F$. odoratum is yellow-pigmented, and, like $F$. breve, may be found in urine cultures; however, $F$. odoratum differs from $F$. breve in being nonsaccharolytic, in reducing nitrite, and in producing urease. Strains of group IIf are Flavobacterium-like, and, although they occur in clinical material, they should not be confused with $F$. breve because strains of group IIf are not pigmented on nutrient agar.

The DNA base composition of $F$. breve (31 to $33 \mathrm{~mol} \% \mathrm{G}+\mathrm{C}$ ) is similar to that of two other Flavobacterium species described by Weeks (29): $F$. aquatile (33\%) and $F$. uliginosum $(32 \%)$. These last two species do not, as far as we know, occur in clinical material, and we have not examined reference strains of the two species. For the foregoing reasons, $F$. aquatile and $F$. uliginosum are not included in Table 4 , but characters, derived from Weeks (29), by which these species may be differentiated from $F$. breve are given in Table 5.

There is no definite evidence that any of our strains were causative of a pathological process. The site of isolation of strain 1 is unknown; strains 3,5 , and 6 were isolated in mixed cultures; strain 4 was possibly a contaminant; and strain 2 may have been causative of a pathological process, but from the brief clinical details obtained, no definite conclusion could be reached (refer to Table 1 for sources of isolation). The three pathogenic organisms (one of which is now

TABLE 4. Characteristics useful in differentiating F. breve from phenetically similar bacteria ${ }^{a}$

\begin{tabular}{|c|c|c|c|c|c|c|}
\hline Test & F. breve & $\begin{array}{l}\text { F. menin- } \\
\text { gosepti- } \\
\text { cum }\end{array}$ & Group IIb & $\begin{array}{c}F \text {. odora- } \\
\text { tum } \\
\text { (Group } \\
\text { M-4f) }\end{array}$ & Group IIf & $\begin{array}{c}\text { Pseudo- } \\
\text { monas mal- } \\
\text { tophilia }^{h}\end{array}$ \\
\hline Acid from ASS' glucose & $6 / 7^{d}$ & $8 / 9$ & + & - & - & $45 / 77$ \\
\hline Acid from ASS glycerol & - & $8 / 9$ & $3 / 4$ & - & - & - \\
\hline Acid from ASS maltose & $6 / 7$ & + & + & - & - & $75 / 77$ \\
\hline Acid from ASS trehalose & - & + & + & - & - & - \\
\hline Alkali production on Christensen citrate ..... & - & $1 / 9$ & $1 / 4$ & - & - & $57 / 62$ \\
\hline Esculin hydrolysis $\ldots \ldots \ldots \ldots \ldots \ldots \ldots$ & - & + & + & - & - & $42 / 59$ \\
\hline Growth at $42^{\circ} \mathrm{C}$ & - & $3 / 9$ & $2 / 4$ & - & + & $19 / 55$ \\
\hline Lysine decarboxylase & - & - & - & - & - & $75 / 85$ \\
\hline Motility at room temperature $\ldots \ldots \ldots \ldots$ & - & - & - & - & - & + \\
\hline Nitrite reduction $\ldots \ldots \ldots \ldots \ldots$ & - & $1 / 9$ & $1 / 4$ & + & - & $1 / 56$ \\
\hline Pigment production on tyrosine. & - & $4 / 9$ & $3 / 4$ & $3 / 10$ & + & $78 / 93$ \\
\hline Starch hydrolysis . . . . . . . . . & - & - & + & - & $1 / 16$ & - \\
\hline Tyrosine hydrolysis & - & - & $2 / 4$ & $9 / 10$ & - & $84 / 93$ \\
\hline Urease production & - & - . & - & + & - & $9 / 69$ \\
\hline Yellow pigment production & + & $5 / 9$ & + & + & - & $7 / 119$ \\
\hline$\beta$-Galactosidase production & - & + & $1 / 4$ & - & - & $9 / 60$ \\
\hline
\end{tabular}

"Symbols: +, all strains tested positive; -, all strains tested negative. The phenotypic results were derived from this study and from NCTC unpublished data.

${ }^{b}$ Not all strains of this taxon were tested in every test.

${ }^{c}$ ASS, Ammonium-salt-sugar medium.

${ }^{d}$ Number of strains showing characters per number of strains tested. 
TABLE 5. Characteristics useful for differentiating $F$. breve from some other Flavobacterium spp. with similar DNA base compositions

\begin{tabular}{|c|c|c|c|}
\hline Test & $\begin{array}{c}\text { F. aqua- } \\
\text { tile }^{a}\end{array}$ & F. breve & $\begin{array}{l}\text { F. uligi- } \\
\text { nosum }^{a}\end{array}$ \\
\hline Grows at $37^{\circ} \mathrm{C}$ & - & $6 / 7^{c}$ & - \\
\hline Requires added $\mathrm{NaCl}$ & - & - & + \\
\hline Hydrolysis of agar & - & - & + \\
\hline Acid from lactose. & - & - & + \\
\hline Acid from sucrose & + & - & + \\
\hline Indole $\ldots \ldots \ldots$ & - & + & - \\
\hline $\begin{array}{l}\mathrm{NO}_{3} \text { to } \mathrm{NO}_{2} \ldots \ldots \\
\text { Isolated from marine }\end{array}$ & en- & - & + \\
\hline vironment $\ldots . .$. & $\ldots-$ & - & + \\
\hline
\end{tabular}

${ }^{a}$ Results are those of Weeks (29).

${ }^{b}$ Results are taken from the present study.

c Number of strains showing characters per number of strains tested.

called $F$. breve) described by Mori (25) were obtained by inoculating laboratory animals with canal water. When the injected animals died, organisms recovered from the blood and internal organs were presumed to be pathogenic and to have originated from the canal water. Mori (25) found his short canal bacillus ( $F$. breve) to be pathogenic for guinea pigs, mice, and rabbits but not for pigeons. Only Stutzer and Kwaschnina (27) reported isolating this species from a clinical source, i.e., from the feces of a patient with relapsing fever, although they did not consider this strain to be causative of a pathological process. Even though none of the seven strains herein described appeared to be clinically significant, the revised description of the species will allow other workers to recognize strains of $F$. breve in clinical material, and further studies may perhaps determine whether the species can be causative of a pathological process. If this proves to be the case, the resistance of $F$. breve to therapeutic levels of a wide range of antimicrobial agents (including carbenicillin and gentamicin) to which gram-negative, nonfermentative bacteria might be expected to be susceptible suggests that infections due to this species might prove difficult to treat.

Of all the early names given to the short canal bacillus of Mori (25), the only validly published and legitimate one is Bacillus brevis, the name used by Lustig in 1890 (19). All of the other names are not validly published or are illegitimate either in the use of a specific epithet which is formed from two or more words which do not refer to a single concept (18, Rule 12a) or in the use of a junior synonym; the generic name $P$ seudobacterium Krasil'nikov 1949, to which genus Krasil'nikov (16) transferred this species, is also illegitimate [18, Rule 51b (1)]. Although the generic name Empedobacter, to which Prévot (26) transferred $F$. breve, is validly published (5), it is not a name in common usage and it is not accepted in the eighth edition of Bergey's Manual of Determinative Bacteriology (4). Despite the present unsatisfactory taxonomic status of the genus Flavobacterium, this genus is the best position for $F$. breve at this time.

Chester (6) drew attention to the similarity between the organism now referred to as $F$. breve and Bacillus septicus hominis Mironow 1892. However, the name $B$. septicus hominis was not validly published (18, Rule 12a), and even if the two above-mentioned names were synonymous, the specific epithet breve would have priority as this epithet was the first of the two to be published. Chester (6) also drew attention to the similarity between $F$. breve and Bacterium septicus agrigenus (Flügge) Chester 1897. The latter name was also not validly published (18, Rule 12a), although a name for the species was later validly published, i.e., Pasteurella agrigena Trevisan 1889 (see Index Bergeyana [5]), a year earlier than the publication of the specific epithet breve. However, as there are, according to the World Directory of Collections of Cultures of Microorganisms (23), no reference strains of $P$. agrigena available, it would not appear necessary to further consider the name $P$. agrigena as being synonymous with $F$. breve.

ATCC 14234 is available from the American Type Culture Collection, Rockville, Maryland and three of our strains have been deposited in the National Collection of Type Cultures, including the proposed neotype, CL88/76 (= NCTC 11099); the other two strains are CL626/75 (= NCTC 11162) and CL669/76 $(=$ NCTC 11163).

\section{ACKNOWLEDGMENTS}

We are extremely grateful to $H$. T. March for assistance with the translation of the German text of several papers. $L$. R. Hill kindly translated the Italian text of the paper by Lustig (19). Our thanks are also due to all those who sent us strains of Flavobacterium breve for identification, especially those who also kindly provided additional clinical details relating to the isolation of their strains.

\section{REPRINT REQUESTS}

Reprints are not available.

\section{LITERATURE CITED}

1. American Type Culture Collection. 1976. Catalogue of strains, 12th ed., p. 62. American Type Culture Collection, Rockville, Md.

2. Bergey, D. H., F. C. Harrison, R. S. Breed, B. W. Hammer, and F. M. Huntoon (ed.). 1923. Bergey's manual of determinative bacteriology, p. 116. The Williams \& Wilkins Co., Baltimore.

3. Brenner, D. J., G. R. Fanning, A. V. Rake, and K. E. 
Johnson. 1969. Batch procedure for thermal elution of DNA from hydroxyapatite. Anal. Biochem. 28:447-459.

4. Buchanan, R. E., and N. E. Gibbons (ed.). 1974. Bergey's manual of determinative bacteriology, 8th ed. The Williams \& Wilkins Co., Baltimore.

5. Buchanan, R. E., J. G. Holt, and E. F. Lessel, Jr. 1966 Index Bergeyana. E. \& S. Livingstone Ltd., London.

6. Chester, F. D. 1897. Report of mycologist, p. 20-145. Delaware College Agricultural Experiment Station, 9th Annual Report. Mercantile Printing Co., Wilmington, Del.

7. Chester, F. D. 1901. A manual of determinative bacteriology. Macmillan Co., New York.

8. Cornil, A.-V., and V. Babes. 1890. Les bactéries et leur role dans l'étiologie, l'anatomie et l'histologie pathogiques des maladies infectieuses, 3rd ed. Baillière et Cie, Paris.

9. Cowan, S. T. 1974. Cowan and Steel's manual for the identification of medical bacteria, 2nd ed. Cambridge University Press, London.

10. De Ley, J. 1970. Reexamination of the association between melting point, buoyant density, and chemical base composition of deoxyribonucleic acid. J. Bacteriol. 101:738-754.

11. Eisenberg, J. 1891. Bakteriologische Diagnostik. Leopold Voss, Hamburg.

12. Frankland, P. F., and G. C. Frankland. 1894. Microorganisms in water. Longmans, Green, and Co., London.

13. Holmes, B., S. P. Lapage, and H. Malnick. 1975. Strains of Pseudomonas putrefaciens from clinical material. J. Clin. Pathol. 28:149-155.

14. Holmes, B., J. J. S. Snell, and S. P. Lapage. 1977 Revised description, from clinical isolates, of Flavobac terium odoratum Stutzer and Kwaschnina 1929, and designation of the neotype strain. Int. J. Syst. Bacteriol. 27:330-336.

15. King, E. O., M. K. Ward, and D. E. Raney. 1954. Two simple media for the demonstration of pyocyanin and fluorescin. J. Lab. Clin. Med. 44:301-307.

16. Krasil'nikov, N. A. 1959. Diagnostik der bakterien und actinomyceten. Gustav Fischer, Jena. (The original transfer of Bacillus brevis to Pseudobacterium was published by Krasil'nikov [1949] in the Russian text of this cited translation.)
17. Lapage, S. P., and W. R. Willcox. 1974. A simple method for analysing binary data. J. Gen. Microbiol. 85:376-380.

18. Lapage, S. P., P. H. A. Sneath, E. F. Lessel, V. B. D. Skerman, H. P. R. Seeliger, and W. A. Clark. 1975. International code of nomenclature of bacteria, 1976 revision. American Society for Microbiology, Washington, D.C.

19. Lustig, A. 1890. Diagnostica dei batteri delle acque con una guida alle ricerche batteriologiche e microscopiche. Rosenberg \& Sellier, Torino.

20. Mandel, M., L. Igambi, J. Bergendahl, M. L. Dodson, and E. Scheltgen. 1970. Correlation of melting temperature and cesium chloride buoyant density of bacterial deoxyribonucleic acid. J. Bacteriol. 101:333-338.

21. Marmur, J. 1961. A procedure for the isolation of deoxyribonucleic acid from micro-organisms. J. Mol. Biol. 3:208-218.

22. Marmur, J., and P. Doty. 1962. Determination of the base composition of deoxyribonucleic acid from its thermal denaturation temperature. J. Mol. Biol. 5:109-118.

23. Martin, S. M., and V. B. D. Skerman. 1972. World directory of collections of cultures of microorganisms. Wiley-Interscience, New York.

24. Mez, C. 1898. Mikroskopische Wasseranalyse. Julius Springer, Berlin.

25. Mori, R. 1888. Ueber pathogene Bacterien im Canalwasser. Z. Hyg. 4:47-54.

26. Prévot, A.-R. 1961. Traité de systématique bactérienne. Dunod, Paris.

27. Stutzer, M., and A. Kwaschnina. 1929. In Aussaaten aus den Fäzes des Menschen gelbe Kolonien bildende Bakterien (Gattung Flavobacterium u.a.). Zentralbl. Bakteriol. Parasitenkd. Infektionskr. Hyg. Abt. 1. 113:219-225.

28. Weaver, R. E., H. W. Tatum, and D. G. Hollis. 1972. The identification of unusual pathogenic gram-negative bacteria (Elizabeth $O$. King), preliminary revision. CDC monograph, Public Health Service, Atlanta, Ga.

29. Weeks, O. B. 1974. Genus Flavobacterium Bergey et al. 1923, p. 357. In R. E. Buchanan and N. E. Gibbons (ed.), Bergey's manual of determinative bacteriology, 8th ed. The Williams \& Wilkins Co., Baltimore. 